\title{
Bank erosion of the Tŕstie stream: BANCS model predictions vs. real bank erosion
}

\author{
Zuzana Allmanová ${ }^{1}$, Mária Vlčková ${ }^{1}$, Martin Jankovský' ${ }^{*}$, Matúš Jakubis ${ }^{1}$, Michal Allman ${ }^{1}$ \\ ${ }^{1}$ Department of Forest Harvesting, Logistics and Ameliorations, Faculty of Forestry, Technical University in Zvolen, T.G. Masaryka 24, \\ 96053 Zvolen, Slovakia. \\ ${ }^{2}$ Department of Forestry Technology and Constructions, Faculty of Forestry and Wood Sciences, Czech University of Life Sciences \\ Prague, Kamýcká 129, 16500 Prague 6 - Suchdol, Czechia. \\ * Corresponding author. Tel.: +420 22438 3729. E-mail: jankovskym@fld.czu.cz
}

\begin{abstract}
This paper focused on predicting the bank erosion through the Bank Assessment for Non-point source Consequences of Sediment (BANCS) model on the Tŕstie water stream, located in the western Slovakia. In 2014, 18 experimental sections were established on the stream. These were assessed through the Bank Erosion Hazard Index (BEHI) and the Near Bank Stress (NBS) index. Based on the data we gathered, we constructed two erosion prediction curves. One was for BEHI categories low and moderate, and one for high, very high, and extreme BEHI. Erosion predicted through the model correlated strongly with the real annual bank erosion - for low and moderate BEHI, the $\mathrm{R}^{2}$ was 0.51 , and for high, very high and extreme BEHI, the $\mathrm{R}^{2}$ was 0.66 . Our results confirmed that the bank erosion can be predicted with sufficient precision on said stream through the BANCS model.
\end{abstract}

Keywords: BANCS model; Bank erosion; Prediction curves.

\section{INTRODUCTION}

Bed-forming discharges, caused by heavy rainfall, extreme precipitation, and rapid snow melt in spring, occur in water courses more frequently, due to, among other things, the climate change. Extremely high discharges often lead to extreme catchment erosion rates. Problems caused by siltation of the drinking water reservoirs and erosion of fertile land into seas and oceans are becoming serious. Therefore, scientists and practitioners devote their attention to catchment erosion.

Bull (1997) conducted research of bank erosion in the upper part of the River Severn, UK, which has the total catchment area of $380 \mathrm{~km}^{2}$. She used manual and photo-electronic erosion pins to estimate the bank erosion and observed annual erosion rates between $12.9 \mathrm{~mm} \mathrm{year}^{-1}$ and $460.6 \mathrm{~mm} \mathrm{year}^{-1}$. Similarly, Foucher et al. (2017) studied bank erosion on a small agricultural lowland watershed in France that was strongly affected by anthropogenic pressure. They measured short term bank erosion through a network of erosion pins along the $1400 \mathrm{~m}$ long stream. As a result, they quantified the material transported from the stream during one single winter (2012-2013) and reported the mean erosion rate of $17.7 \mathrm{~mm}$ year $^{-1}$ and a mean volume of transported material of $75 \mathrm{t} \mathrm{km}^{-1}$. Veihe et al. (2011) carried out their study on the Harrested stream in Denmark. They conducted the research on a cohesive streambank that is centrally located within the tile-drained catchment of the stream. Bank erosion rates ranged from 17.6 to $30.1 \mathrm{~mm}$ year $^{-1}$.

On the other hand, Lawler et al. (1999) reported the results of an intensive direct field monitoring of bank erosion rate on 11 sites on $130 \mathrm{~km}$ of the Swale-Ouse catchment, located in northern England and spanning over $3315 \mathrm{~km}^{2}$. They reported that the mean bank erosion ranged from $82.7 \mathrm{~mm}$ to $440.1 \mathrm{~mm}$ over the period of 14.5 months. Laubel et al. (2003) conducted similarly substantial research on 91 banks of 15 Danish streams. They reported mean bank erosion rate $11 \mathrm{~mm}$ year $^{-1}$ and found several site-specific factors that affect bank erosion rate, such as bank angle, bank vegetation cover, overhang, and estimated stream power.
In Central European conditions, among other authors, Jakubis (2014) studied the erosion rates on the Železnobreznický creek. He used manual erosion pins and estimated that the mean bank erosion was $112 \mathrm{~mm}_{\text {year }}{ }^{-1}$. Jakubisová (2014) modelled the effects of extreme discharges on the bank stability and erosion rates of Železnobreznický creek. Through the Bank Stability and Toe Erosion Model she quantified the stability factor and the risk of bank erosion. Rusnák and Lehotský (2014) studied the long term (1987 to 2009) bank erosion of catchments in the north-eastern part of Slovakia through remote sensing. They studied Ondava (13.2 km long section) and Topla (39.8 km long section) and found great lateral dynamics and substantial bank erosion on both streams. During the 19872009 period, about 120 ha of banks were eroded and about 92 ha were accumulated from both streams.

The research mentioned is a small subset of all research that quantifies and predicts bank erosion. The authors constructed their own models, which can, with greater or smaller precision, explain or predict erosion. Most of these models are, however, region specific and have little success in predicting bank erosion outside the region they were constructed. On the other hand, there are models such as the Bank Assessment for Nonpoint source Consequences of Sediment (BANCS) model, described in detail by Rosgen (1996, 1998, 2001a, 2001b, 2006). The BANCS model was tested globally, though most research focuses on the USA (Coryat, 2014; Jennings and Harman, 2001; Sass and Keane, 2012; Van Eps et al., 2004) or India (Bandyopadhyay et al., 2013; Ghosh et al., 2016). Thorough verification of this model in other regions, such as Europe (or more specifically Central Europe and Slovakia) is yet to be done.

The BANCS model consists of two indexes - the Bank Erosion Hazard Index (BEHI), and the Near Bank Stress Index (NBS) (Rosgen, 1996, 2001a, 2006, 2008). The BEHI serves to estimate the susceptibility of a bank to erosion. It is based on variables that influence the erosion intensity. The NBS index is a practical method to evaluate shear stress which acts upon a studied bank. The NBS approximates the erosional force of the outer one third of the water column acting on the eroded 
bank (cutbank) at the bank-full stage flow. The direct erosion measurements and the subsequent BEHI and NBS index determination enable the construction of the erosion prediction curves for particular streams. Based on the predictions made through the BANCS model, we can localize stream sections that most need the stabilization measures.

This paper focuses on assessing, whether it is suitable to use the BANCS model and its prediction curves on a water stream in Slovakia. Other authors, who supported the use of the BANCS model for bank erosion predictions, focused on larger streams, whereas we focused on the model's suitability for small watersheds. This could aid caretaking of small watersheds, which are commonly the source of flash floods. We also determined whether higher BEHI and NBS indexes truly represent greater annual bank erosion.

\section{MATERIALS AND METHODS}

In May 2014, we established 18 experimental sections (ES) on the Tŕstie stream (Fig. 1). We established the ES between
13.70 and $16.53 \mathrm{~km}$ of the stream $(14.65 \%$ of the stream length). The total length of the ES was $307 \mathrm{~m}(1.6 \%$ of the total main channel length). Detailed information about the established ES can be seen in Table 1. On each ES, we chosen one cross section (Table 2) where we inserted a toe pin into the toe of the bank to determine the real annual erosion according to Sass (2011), and measured input data for the BEHI and the NBS index. We also took soil samples from the banks for laboratory analyses of the granularity of the bank material, and evaluated the stratification of the banks.

\section{Study area}

The Tŕstie stream and its watershed (hydrological number 4-21-09-065) lays in the Biele Karpaty and Myjavská pahorkatina mesoregions. The Tŕstie stream stems on the eastern part of Čupec hill in Javorinská heights, elevated $212 \mathrm{~m}$ above sea level (GPS coordinates: 4848'52.28"N, 17³8'55.38"E). In the village Hrachovište, Tŕstie flows into Jablonka stream, elevated $212 \mathrm{~m}$ above sea level. The characteristics of Tŕstie

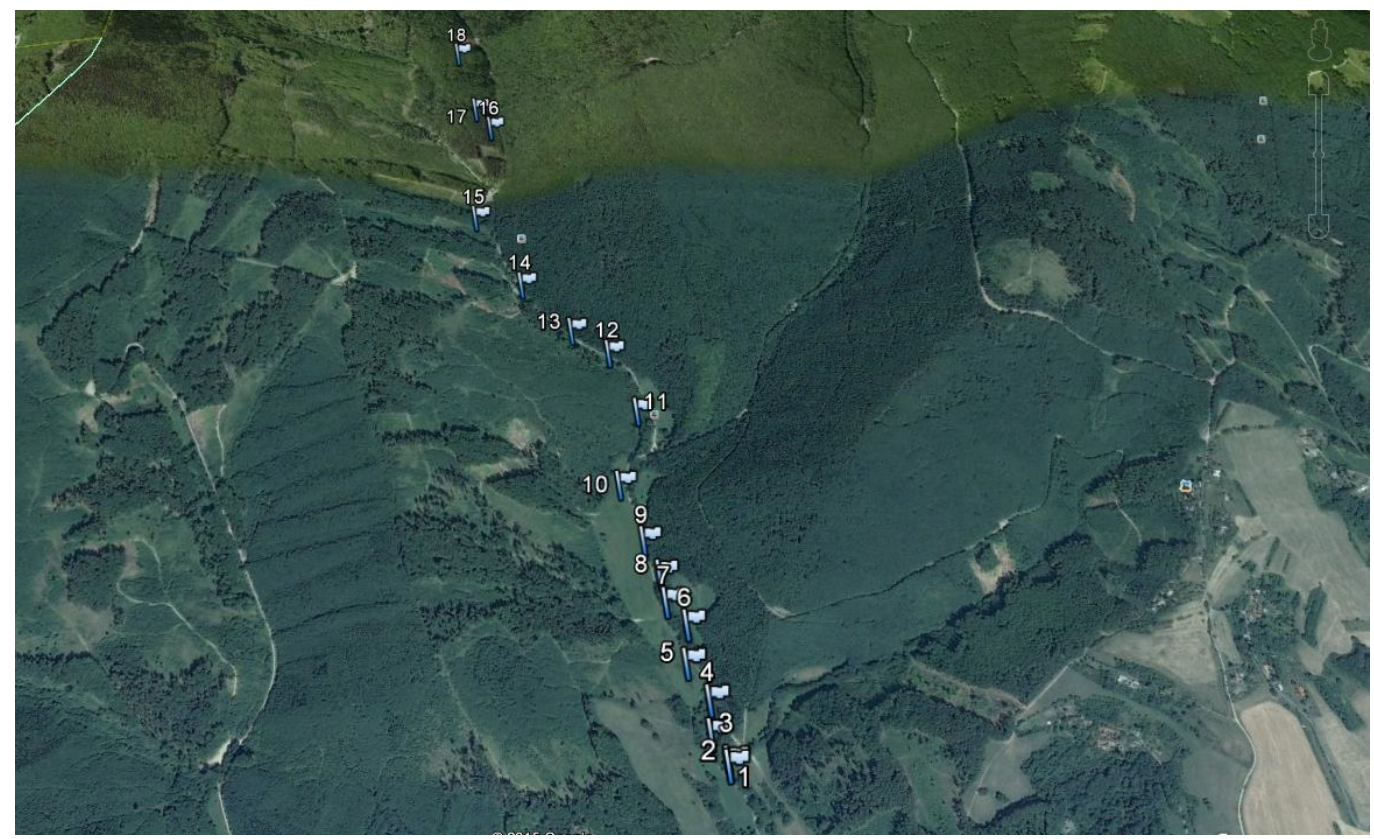

Fig. 1. Localization of the experimental sections on Tŕstie creek.

Table 1. Information about the experimental sections established on Tŕstie creek.

\begin{tabular}{|l|c|c|c|}
\hline & $\begin{array}{c}\text { Distance from the mouth } \\
\text { of the watershed }(\mathrm{km})\end{array}$ & $\begin{array}{c}\text { Altitude } \\
(\mathrm{m} \text { above the sea level })\end{array}$ & $\begin{array}{c}\text { GPS coordinates } \\
(\mathrm{m})\end{array}$ \\
\hline ES1 & 13.70 & 396 & $48^{\circ} 49^{\prime} 20.4^{\prime \prime} \mathrm{N}, 17^{\circ} 38^{\prime} 78.4^{\prime \prime} \mathrm{E}$ \\
\hline ES2 & 13.80 & 396 & $48^{\circ} 49^{\prime} 19.7^{\prime \prime} \mathrm{N}, 17^{\circ} 38^{\prime} 78.1^{\prime \prime} \mathrm{E}$ \\
\hline ES3 & 13.90 & 397 & $48^{\circ} 49^{\prime} 23.9^{\prime \prime} \mathrm{N}, 17^{\circ} 38^{\prime} 75.4^{\prime \prime} \mathrm{E}$ \\
\hline ES4 & 13.95 & 401 & $48^{\circ} 49^{\prime} 28.5^{\prime \prime} \mathrm{N}, 17^{\circ} 38^{\prime} 75.7^{\prime \prime} \mathrm{E}$ \\
\hline ES5 & 14.01 & 409 & $48^{\circ} 49^{\prime} 33.6^{\prime \prime} \mathrm{N}, 17^{\circ} 38^{\prime} 71.9^{\prime \prime} \mathrm{E}$ \\
\hline ES6 & 14.20 & 410 & $48^{\circ} 49^{\prime} 39.4^{\prime \prime} \mathrm{N}, 17^{\circ} 38^{\prime} 72.5^{\prime \prime} \mathrm{E}$ \\
\hline ES7 & 14.30 & 414 & $48^{\circ} 49^{\prime} 43.1^{\prime \prime} \mathrm{N}, 17^{\circ} 38^{\prime} 68.8^{\prime \prime} \mathrm{E}$ \\
\hline ES8 & 14.36 & 415 & $48^{\circ} 49^{\prime} 47.6^{\prime \prime} \mathrm{N}, 17^{\circ} 38^{\prime} 68.2^{\prime \prime} \mathrm{E}$ \\
\hline ES9 & 14.41 & 419 & $48^{\circ} 49^{\prime} 53.1^{\prime \prime} \mathrm{N}, 17^{\circ} 38^{\prime} 65.1^{\prime \prime} \mathrm{E}$ \\
\hline ES10 & 14.50 & 419 & $48^{\circ} 49^{\prime} 63.0^{\prime \prime} \mathrm{N}, 17^{\circ} 38^{\prime} 60.7^{\prime \prime} \mathrm{E}$ \\
\hline ES11 & 14.75 & 442 & $48^{\circ} 49^{\prime} 76.3^{\prime \prime} \mathrm{N}, 17^{\circ} 38^{\prime} 65.3^{\prime \prime} \mathrm{E}$ \\
\hline ES12 & 14.98 & 453 & $48^{\circ} 49^{\prime} 88.0^{\prime \prime} \mathrm{N}, 17^{\circ} 38^{\prime} 59.6^{\prime \prime} \mathrm{E}$ \\
\hline ES13 & 15.11 & 468 & $48^{\circ} 49^{\prime} 92.2^{\prime \prime} \mathrm{N}, 17^{\circ} 38^{\prime} 51.0^{\prime \prime} \mathrm{E}$ \\
\hline ES14 & 15.34 & 478 & 20 \\
\hline ES15 & 15.67 & $58^{\circ} 50^{\prime} 02.2^{\prime \prime} \mathrm{N}, 17^{\circ} 38^{\prime} 39.3^{\prime \prime} \mathrm{E}$ \\
\hline ES16 & 16.12 & 500 & 20 \\
\hline ES17 & 16.23 & 519 & 15 \\
\hline ES18 & 16.53 & 535 & 20 \\
\hline
\end{tabular}


Table 2. Information about dimensions of experimental cross sections.

\begin{tabular}{|c|c|c|c|c|l|}
\hline & $\begin{array}{c}\text { Mean depth } \\
\text { of channel } \\
(\mathrm{m})\end{array}$ & $\begin{array}{c}\text { Maximum } \\
\text { depth of } \\
\text { channel }(\mathrm{m})\end{array}$ & $\begin{array}{c}\text { Area of } \\
\text { channel }\left(\mathrm{m}^{2}\right)\end{array}$ & $B(\mathrm{~m})^{\mathrm{a}}$ & $b(\mathrm{~m})^{\mathrm{b}}$ \\
\hline ES1 & 0.292 & 0.40 & 1.286 & 5.05 & 2.35 \\
\hline ES2 & 0.298 & 0.55 & 0.993 & 3.8 & 2.4 \\
\hline ES3 & 0.318 & 0.42 & 1.006 & 3.4 & 2.35 \\
\hline ES4 & 0.845 & 1.03 & 3.304 & 3.8 & 2.95 \\
\hline ES5 & 0.595 & 0.77 & 1.828 & 3.3 & 2.45 \\
\hline ES6 & 0.692 & 0.95 & 2.224 & 3.3 & 1.9 \\
\hline ES7 & 0.855 & 1.15 & 3.095 & 4.1 & 2.5 \\
\hline ES8 & 0.609 & 0.73 & 2.34 & 3.75 & 2.9 \\
\hline ES9 & 0.454 & 0.72 & 1.387 & 3.15 & 1.6 \\
\hline ES10 & 0.796 & 1.05 & 3.273 & 4.2 & 2 \\
\hline ES11 & 0.333 & 0.48 & 0.916 & 2.85 & 1.8 \\
\hline ES12 & 0.501 & 0.62 & 1.841 & 4.4 & 2.75 \\
\hline ES13 & 0.781 & 1.17 & 2.984 & 3.8 & 2 \\
\hline ES14 & 0.564 & 0.72 & 1.428 & 3.05 & 1.6 \\
\hline ES15 & 0.441 & 0.61 & 1.02 & 2.45 & 1.3 \\
\hline ES16 & 0.408 & 0.51 & 0.878 & 2.95 & 1 \\
\hline ES17 & 0.402 & 0.58 & 1.002 & 2.75 & 0.9 \\
\hline ES18 & 0.324 & 0.47 & 0.829 & 2.55 & 1.2 \\
\hline
\end{tabular}

The dimensions were determined for the bankfull conditions of the channel. $B(\mathrm{~m})^{\mathrm{a}}=$ the width of the channel in the banks, $b(\mathrm{~m})^{\mathrm{b}}=$ the width of the channel in the bed

watershed are as follows: watershed area $S_{p}=41.55 \mathrm{~km}^{2}$; length of main channel $L=19.31 \mathrm{~km}$; length of tributaries $L_{t r}=16.32 \mathrm{~km}$; stream network density $r=0.85 \mathrm{~km} \mathrm{~km}^{-2}$; length of the watershed divide $O=38.65 \mathrm{~km}$; length of thalweg $L_{t g}=19.90 \mathrm{~km}$; mean width of the watershed $B_{w}=2.08 \mathrm{~km}$; absolute gradient of stream $\Delta H_{s}=440.48 \mathrm{~m}$; absolute gradient of watershed $\Delta H_{w}=630.01 \mathrm{~m}$; slope of the thalweg $I_{t g}=3.14 \%$; average slope of watershed $I_{w}=9.77 \%$; average slope of the main channel $I_{s}=2.28 \%$; average altitude of watershed $\varnothing H_{w}=525.99 \mathrm{~m}$ above the sea level. Estimated T-year discharges according to OTN ŽP 3112-1:03 are as follows: $Q_{100}=31.05 \mathrm{~m}^{3} \mathrm{~s}^{-1}, Q_{50}=26.23 \mathrm{~m}^{3} \mathrm{~s}^{-1}$ a $Q_{1}=4.65 \mathrm{~m}^{3} \mathrm{~s}^{-1}$.

Furthermore, we estimated the mean annual discharge $Q_{a}=0.37 \mathrm{~m}^{3} \mathrm{~s}^{-1}$ according to Szolgay et al. (1997). Szolgay et al. (1997) based their estimation on formula (Eq. 1) and data from 54 meteorological stations in Slovakia. They derived the empirical relationships (Eq. 2) for the Slovak conditions. These were subsequently used in equation (Eq. 3 ) to estimate $Q_{a}$.

$\bar{Z}=\bar{O}+\bar{E}(\mathrm{~mm})$

$\bar{O}=\bar{Z} \cdot\left(1-\frac{E P_{i S R}}{\sqrt{0.809 \cdot E P_{i S R}^{2}+\bar{Z}^{2}}}\right) \quad(\mathrm{mm})$

$Q a=\frac{\bar{O} \cdot S p \cdot 10^{3}}{t}\left(\mathrm{~m}^{3} \mathrm{~s}^{-1}\right)$

where: $\bar{Z}$ is the mean long term annual precipitation in the watershed (mm); $\bar{O}$ is the mean long term annual runoff in the watershed (mm); $\bar{E}$ is the mean long term annual climatic evaporation in the watershed $(\mathrm{mm}) ; E P_{i S R}$ is the potential evaporation index SR $=260.822+37.920 \bar{T}+0.077 \bar{T}^{3}(\mathrm{~mm}) ; \bar{T}$ is the mean long term annual temperature in the watershed $\left({ }^{\circ} \mathrm{C}\right)$; and $\mathrm{t}$ is the constant of 31557600 seconds (one year expressed in seconds).

Geologically the watershed is situated in the flysch strata. The most frequent soil types are Cambisols (50\% of the watershed area, mostly in the northern part of the watershed), luvi-

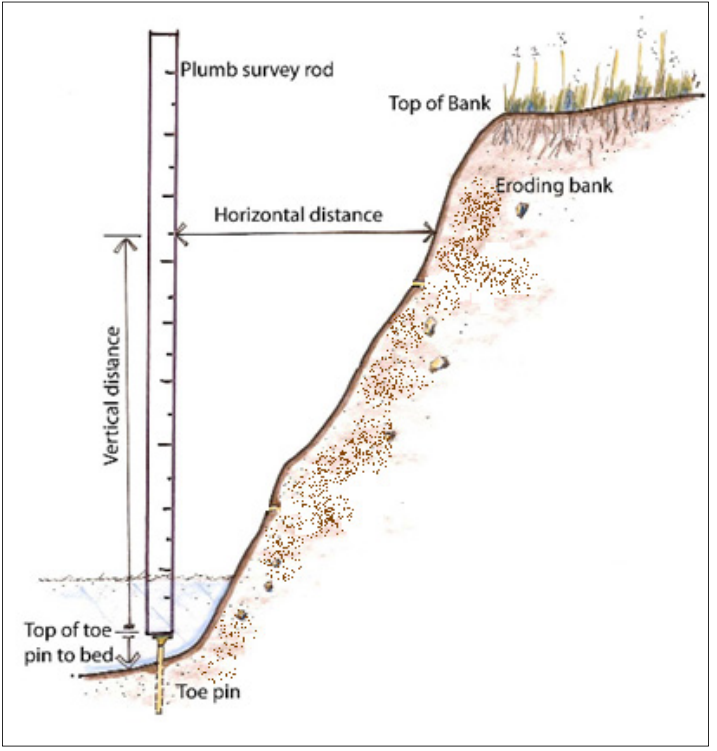

Fig. 2. Measurement of annual stream bank erosion. The toe pin is used as a control point at the toe of bank (edited Sass, 2011).

sols cover about $20 \%$ of the watershed, rendzic and calcaric soils cover about $15 \%$ of the watershed, and planosols formed on about $5 \%$ of the watershed area. The average annual precipitation in the watershed is between $650 \mathrm{~mm}$ in the lower part of watershed, to $900 \mathrm{~mm}$ in the upper part of watershed (Stankoviansky and Frandofer, 2012).

Forests cover almost half of the watershed (47\%). Arable land covers another $27 \%$, pastures cover $14 \%$, and gardens and developed land cover about $12 \%$ of the watershed area. The stream section where we conducted our research is located springwards of Topolecká village. The section is almost fully covered by forest $(98 \%)$ and the remaining $2 \%$ of the area are covered by pasture. We set-up no ES within the developed area.

According to Stankoviansky and Frandofer (2012), the landscape of the watershed was originally fully forested. However, it was deforested during the $14^{\text {th }}$ century, when a nearby town of Stará Turá was developed. Subsequently, land use shifted to pasture and remained in this mode of use until the collectivization of agriculture, which took place during the second half of the $20^{\text {th }}$ century. Collectivization, and the change of land structure it brought, increased the intensity of rainfall and snowmelt processes, frequency and intensity of mud floods, and the intensity of tillage erosion. Stankoviansky and Fandofer (2012) also mention forest disturbances as important events, that affect bank erosion. In the recorded history, windthrows that occurred in June 1999 and May 2010 caused the most severe damage within the watershed.

\section{Measurements of real bank erosion}

We started measuring the real annual erosion rates (EB) on May 2014 using erosion toe pins, according to Sass (2011). The $50 \mathrm{~cm}$ long, steel toe pins were installed perpendicularly into the toe of the banks (Fig. 2). We recorded the location of the toe pins using a GARMIN Colorado300 GPS device, placed a plumb survey rod perpendicularly to the toe pins, and measured the horizontal distances from the rod to the bank. After one year (on May 2015), we re-measured the horizontal distances at the same height levels. We then plotted the initial and re-measured shape of the bank, calculated the EB in $\mathrm{m}^{2}$, and converted the EB outcome to $\mathrm{m}^{3} \mathrm{~m}^{-1}$ (the volume of eroded material per one meter of the ES length). 


\section{The BEHI}

We determined the BEHI score according to Rosgen (2006). We evaluated seven parameters on each ES (Table 3): (a) the ratio of the height of the studied bank ( $\mathrm{BH}$; see Fig. 3) to bankfull height ( $B F H$; see Fig. 3); (b) the ratio of root depth $(R D)$ to $B H$; (c) weighed root density $(W R)$; (d) bank angle $(B A)$; (e) surface protection $(S P)$; (f) bank material $(\mathrm{BM})$; and (g) stratification of the bank material (SBM).

We measured the $B H, B F H, R D$, and $B A$, and evaluated the $\mathrm{BM}$ through the sieve and densimetric tests of soil samples we took from each ES's bank. The assessments of the $W R$ and $S P$ were visual as well as the assessment of the SBM. To stratify the bank material, we assessed the bank layers.

To determine the total BEHI score, we first input the data into the BEHI worksheet (Rosgen, 2008) and converted them through the corresponding nomograms (Rosgen, 2006). Parameters (a) to (e) reached one of six states: very low ( $0-2$ points), low ( $2-4$ points), moderate ( $4-6$ points), high (6-8 points), very high (8-9 points), and extreme (9-10 points). For parameter (f), we either added or subtracted 5-10 points to the total BEHI score, depending on the bank material (Rosgen, 2008).

Table 3. Assessment of individual experimental sections through the BEHI index.

\begin{tabular}{|c|c|c|c|c|c|c|c|c|c|c|c|c|}
\hline ES & & $B H(\mathrm{~m})$ & $B F H(\mathrm{~m})$ & $B H / B F H(\mathrm{~m})$ & $R D(\mathrm{~m})$ & $R D / B H(\mathrm{~m})$ & $R(\%)$ & $W R(\%)$ & $S P(\%)$ & $B A\left(^{\circ}\right)$ & BEHI & BEHI total \\
\hline \multirow[t]{2}{*}{1} & Value & 1.15 & 0.34 & 3.38 & $\begin{array}{c}0.84 \\
\mathrm{H}^{\mathrm{a}}, \mathrm{G}^{\mathrm{b}}, \mathrm{S}^{\mathrm{d}}\end{array}$ & 0.73 & 49 & 35.7 & 50 & 63 & & \\
\hline & Index & & & 10 & & 2.8 & & 5.4 & 4.3 & 4.2 & 26.7 & $31.7 \mathrm{H}$ \\
\hline \multirow[t]{2}{*}{2} & Value & 2.32 & 0.23 & 10.08 & $\begin{array}{c}0.39 \\
\mathrm{H}^{\mathrm{a}}, \mathrm{F}^{\mathrm{c}} \\
\end{array}$ & 0.16 & 40 & 6.72 & 5 & 61 & & \\
\hline & Index & & & 10 & & 7.9 & & 8.8 & 10 & 4.0 & 40.7 & $45.7 \mathrm{VH}$ \\
\hline \multirow[t]{2}{*}{3} & Value & 0.58 & 0.32 & 1.81 & $\begin{array}{c}0.19 \\
\mathrm{H}^{\mathrm{a}}, \mathrm{G}^{\mathrm{b}} \\
\end{array}$ & 0.32 & 54 & 17.3 & 10 & 74 & & \\
\hline & Index & & & 7.2 & & 5.6 & & 7.7 & 10 & 5.3 & 35.8 & $35.8 \mathrm{H}$ \\
\hline \multirow[t]{2}{*}{4} & Value & 1.11 & 0.94 & 1.38 & $\begin{array}{c}0.72 \\
\mathrm{H}^{\mathrm{a}}, \mathrm{T}^{\mathrm{e}} \\
\end{array}$ & 0.64 & 41 & 26.2 & 10 & 52 & & \\
\hline & Index & & & 4.5 & & 3.2 & & 6.2 & 10 & 3.5 & 27.4 & $27.4 \mathrm{M}$ \\
\hline \multirow[t]{2}{*}{5} & Value & 1.03 & 0.57 & 1.80 & $\begin{array}{c}0.18 \\
\mathrm{H}^{\mathrm{a}}\end{array}$ & 0.78 & 51 & 39.9 & 0 & 60 & & \\
\hline & Index & & & 7.2 & & 2.7 & & 5.0 & 10 & 3.9 & 28.8 & $28.8 \mathrm{M}$ \\
\hline \multirow[t]{2}{*}{6} & Value & 1.56 & 0.91 & 1.71 & $\begin{array}{c}0.58 \\
\mathrm{H}^{\mathrm{a}}, \mathrm{T}^{\mathrm{e}} \\
\end{array}$ & 0.37 & 41 & 15.2 & 10 & 71 & & \\
\hline & Index & & & 6.8 & & 5.2 & & 8.0 & 10 & 5.0 & 35 & $35 \mathrm{H}$ \\
\hline \multirow[t]{2}{*}{7} & Value & 1.09 & 0.65 & 1.67 & $\begin{array}{c}0.49 \\
\mathrm{H}^{\mathrm{a}}, \mathrm{S}^{\mathrm{d}} \\
\end{array}$ & 0.44 & 56 & 24.6 & 10 & 76 & & \\
\hline & Index & & & 6.7 & & 4.1 & & 6.3 & 10 & 5.4 & 32.5 & $47.5 \mathrm{VH}$ \\
\hline \multirow[t]{2}{*}{8} & Value & 0.87 & 0.72 & 1.2 & $\begin{array}{c}0.73 \\
\mathrm{H}^{\mathrm{a}}, \mathrm{T}^{\mathrm{e}}, \mathrm{S}^{\mathrm{d}}\end{array}$ & 0.83 & 57 & 47.3 & 45 & 87 & & \\
\hline & Index & & & 3.9 & & 2.2 & & 4.3 & 4.6 & 7.7 & 22.7 & $30.2 \mathrm{H}$ \\
\hline \multirow[t]{2}{*}{9} & Value & 0.76 & 0.58 & 1.31 & $\begin{array}{r}0.62 \\
\mathrm{H}^{\mathrm{a}}, \mathrm{S}^{\mathrm{d}} \\
\end{array}$ & 0.81 & 62 & 50.2 & 10 & 90 & & \\
\hline & Index & & & 4.4 & & 2.3 & & 4.1 & 10 & 8.0 & 28.8 & $33.8 \mathrm{H}$ \\
\hline \multirow[t]{2}{*}{10} & Value & 0.82 & 0.48 & 1.70 & $\begin{array}{c}0.37 \\
S^{d} \\
\end{array}$ & 0.45 & 35 & 15.7 & 10 & 37 & & \\
\hline & Index & & & 6.8 & & 4.1 & & 8.0 & 10 & 2.8 & 31.7 & $31.7 \mathrm{H}$ \\
\hline \multirow[t]{2}{*}{11} & Value & 0.57 & 0.45 & 1.26 & $\begin{array}{r}0.46 \\
\mathrm{H}^{\mathrm{a}}, \mathrm{S}^{\mathrm{d}} \\
\end{array}$ & 0.80 & 30 & 24.6 & 35 & 56 & & \\
\hline & Index & & & 3.9 & & 2.4 & & 6.3 & 5.5 & 3.7 & 21.8 & $21.8 \mathrm{M}$ \\
\hline \multirow[t]{2}{*}{12} & Value & 1.06 & 0.51 & 2.07 & $\begin{array}{c}0.78 \\
\mathrm{H}^{\mathrm{a}}, \mathrm{S}^{\mathrm{d}} \\
\end{array}$ & 0.73 & 59 & 43.1 & 75 & 45 & & \\
\hline & Index & & & 8.1 & & 2.6 & & 4.8 & 2.2 & 3.1 & 20.8 & $25.8 \mathrm{M}$ \\
\hline \multirow[t]{2}{*}{13} & Value & 1.07 & 0.82 & 1.30 & $\begin{array}{c}0.76 \\
\mathrm{H}^{\mathrm{a}}, \mathrm{T}^{\mathrm{e}}, \mathrm{S}^{\mathrm{d}} \\
\end{array}$ & 0.71 & 56 & 39.7 & 40 & 46 & & \\
\hline & Index & & & 4.4 & & 2.7 & & 5.0 & 5.0 & 3.2 & 20.3 & $25.3 \mathrm{M}$ \\
\hline \multirow[t]{2}{*}{14} & Value & 0.78 & 0.78 & 1.0 & $\begin{array}{r}0.46 \\
\mathrm{H}^{\mathrm{a}}, \mathrm{G}^{\mathrm{b}} \\
\end{array}$ & 0.59 & 64 & 37.7 & 70 & 53 & & \\
\hline & Index & & & 0 & & 3.3 & & 5.3 & 2.7 & 3.5 & 14.8 & $19.8 \mathrm{~L}$ \\
\hline \multirow[t]{2}{*}{15} & Value & 1.03 & 0.62 & 1.66 & $\begin{array}{c}0.43 \\
\mathrm{H}^{\mathrm{a}} \\
\end{array}$ & 0.41 & 35 & 14.3 & 55 & 69 & & \\
\hline & Index & & & 6.6 & & 4.5 & & 8.1 & 4.0 & 4.7 & 27.9 & $32.9 \mathrm{H}$ \\
\hline \multirow[t]{2}{*}{16} & Value & 0.58 & 0.58 & 1.0 & $\begin{array}{r}0.49 \\
\mathrm{H}^{\mathrm{a}}, \mathrm{S}^{\mathrm{d}} \\
\end{array}$ & 0.84 & 42 & 35.2 & 95 & 46 & & \\
\hline & Index & & & 0 & & 2.1 & & 5.4 & 0.5 & 3.1 & 11.1 & $16.1 \mathrm{~L}$ \\
\hline \multirow[t]{2}{*}{17} & Value & 0.68 & 0.68 & 1.0 & $\begin{array}{c}0.48 \\
\mathrm{H}^{\mathrm{a}}, \mathrm{F}^{\mathrm{c}} \mathrm{G}^{\mathrm{b}}\end{array}$ & 0.70 & 45 & 31.5 & 85 & 44 & & \\
\hline & Index & & & 0 & & 2.7 & & 5.7 & 1.5 & 3.0 & 12.9 & $17.9 \mathrm{~L}$ \\
\hline \multirow[t]{2}{*}{18} & Value & 0.64 & 0.28 & 2.28 & $\begin{array}{l}0.37 \\
\mathrm{H}^{\mathrm{a}}\end{array}$ & 0.57 & 33 & 18.8 & 70 & 40 & & \\
\hline & Index & & & 8.2 & & 3.5 & & 7.8 & 2.7 & 2.9 & 25.1 & $25.1 \mathrm{M}$ \\
\hline
\end{tabular}

$\mathrm{H}^{\mathrm{a}}=$ Herbs: Impatiens noli-tagere, Petasites hybridus, Geranium robertianum, Veronica montana; $\mathrm{G}^{\mathrm{b}}=$ Grass: Carex sp.; $\mathrm{F}^{\mathrm{c}}=$ Ferns: Athyrium filix - femina; $\mathrm{S}^{\mathrm{d}}=$ Shrubs: Sambucus nigra, Padus racemossa, $\mathrm{T}^{\mathrm{e}}=$ Trees: Corrylus avellana, Fagus sylvatica, Fraxinus excelsior 


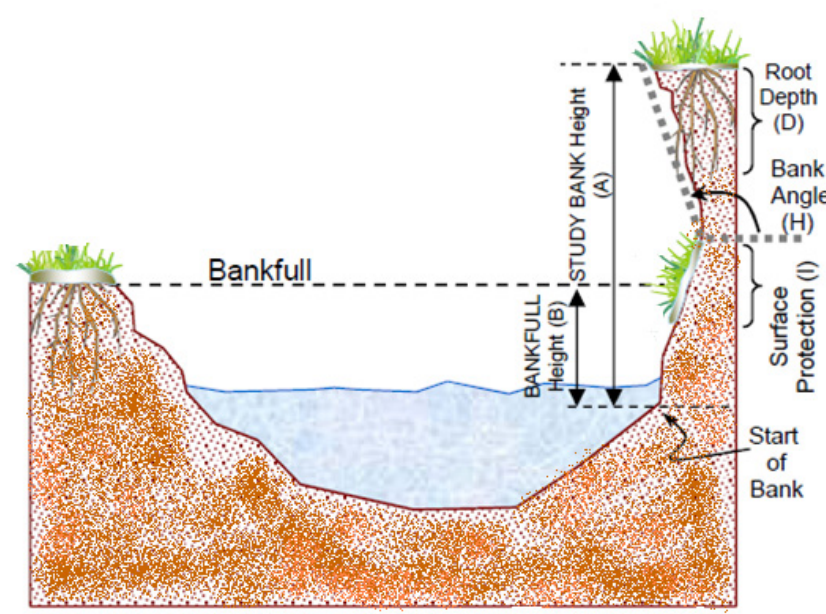

Fig. 3. BEHI characteristics (Rosgen, 2006).

Legend: Bank height $(\mathrm{BH})$ : is a height from start of a bank (point where is set into the bed steel pin) to the top of a bank; Bankfull height (BFH): is height from start of a bank (point where is set into the bed steel pin) to bankfull position; Surface protection (SP): is visually estimated as a percentage of bank covered by plants, trees, shrubs, or woody debris, boulders or other objects which can help prevent bank against erosion; Root density (RD): Is visual assessment of density of vegetation roots growing on a banks.

As for parameter (g), we added five points to the BEHI score if: (i) two separate layers were present; (ii) the layers spanned from the bank toe to the bankfull height; (iii) at least one of the layers consisted of an erosion prone material (such as sand, gravel or their combination). We added ten points to the BEHI score if more than two layers were present and conditions (ii) and (iii) were valid (Rosgen, 2008). Finally, we summed the points obtained for each parameter to determine the BEHI for the studied bank. The banks of each ES were then put into one of six categories of total BEHI index, thus estimating their erodibility potential - very low ( $<9.9$ points), low (10-19.9), moderate (20-29.9), high (30-39.9), very high (40-45), and extreme (45.1-50 points).

\section{The NBS index}

Rosgen (1996, 2001b) presents seven methods to determine the NBS index. In our research, we used method no. five, which uses the share of near bank maximum depth $\left(H_{\max }\right)$ and mean depth of channel $\left(H_{\sigma}\right)$ at bankfull stage flow (Table 4). We measured the depth of the channel for bankfull stage each $0.5 \mathrm{~m}$ of the channel's width to establish the $H_{\max }$ and $H_{\sigma}$ at the bankfull stage. NBS index can reach six levels (Table 5): very low $(\mathrm{VL})$, low $(\mathrm{L})$, moderate $(\mathrm{M})$, high $(\mathrm{H})$, very high $(\mathrm{VH})$, extreme (E) (Rosgen, 1996, 2001b, 2006, 2008). Higher NBS index values indicate larger bank erosion.
Table 4. Assessment of individual experimental sections by the NBS index.

\begin{tabular}{|l|c|c|c|c|}
\hline ES & $H_{\max }$ & $H_{\odot}$ & $H_{\max } / H_{\odot}$ & NBS index \\
\hline 1 & 0.41 & 0.33 & 1.24 & $\mathrm{~L}$ \\
\hline 2 & 0.55 & 0.29 & 1.89 & $\mathrm{H}$ \\
\hline 3 & 0.42 & 0.31 & 1.32 & $\mathrm{~L}$ \\
\hline 4 & 1.03 & 0.67 & 1.53 & $\mathrm{M}$ \\
\hline 5 & 0.77 & 0.59 & 1.30 & $\mathrm{~L}$ \\
\hline 6 & 0.95 & 0.69 & 1.37 & $\mathrm{~L}$ \\
\hline 7 & 1.15 & 0.69 & 1.66 & $\mathrm{M}$ \\
\hline 8 & 0.73 & 0.48 & 1.52 & $\mathrm{M}$ \\
\hline 9 & 0.27 & 0.45 & 1.57 & $\mathrm{M}$ \\
\hline 10 & 1.05 & 0.79 & 1.32 & $\mathrm{~L}$ \\
\hline 11 & 0.50 & 0.33 & 1.51 & $\mathrm{M}$ \\
\hline 12 & 0.62 & 0.48 & 1.29 & $\mathrm{~L}$ \\
\hline 13 & 1.17 & 0.89 & 1.31 & $\mathrm{~L}$ \\
\hline 14 & 0.72 & 0.56 & 1.28 & $\mathrm{~L}$ \\
\hline 15 & 0.61 & 0.44 & 1.38 & $\mathrm{~L}$ \\
\hline 16 & 0.51 & 0.46 & 1.10 & $\mathrm{~L}$ \\
\hline 17 & 0.58 & 0.49 & 1.18 & $\mathrm{~L}$ \\
\hline 18 & 0.47 & 0.32 & 1.46 & $\mathrm{~L}$ \\
\hline
\end{tabular}

\section{Statistical analyses}

After gathering the input data and determining the BEHI and NBS index, we assessed the relationships between the aforementioned characteristics through the regression and correlation analyses.

We first verified the hypothesis that higher BEHI values indicated higher EB through a regression and correlation analysis of the relationship between the BEHI and the EB. Similarly, we assessed the relationship between the NBS index and the EB. After verifying whether or not the relationships were statistically significant, we constructed the erosion prediction curves as a graphical representation of the relationship between the NBS index and the EB. All statistical analyses as well as the construction of the erosion prediction curves were conducted in the STATISTICA 10.0 program.

\section{Construction of the prediction curves for the stream}

We constructed the prediction curves by plotting the NBS values on the $\mathrm{X}$ axis, and the corresponding $\mathrm{EB}$ on the $\mathrm{Y}$ axis. The resulting linear regression lines represented individual categories of the BEHI. These trend lines were then used to predict the bank erosion. When constructing the prediction curves, we classified individual ES according to their BEHI category. Due to insufficient data in some categories, we merged the neighbouring BEHI categories as seen in studies by other authors (Coryat, 2014; Harmel et al., 1999; Kwan and Swanson, 2014; Sass, 2011).

Table 5. The evaluation of NBS index according to used method (Rosgen, 2001a, 2008).

\begin{tabular}{|c|c|c|c|c|c|c|c|}
\hline \multirow[t]{2}{*}{ Index NBS } & \multicolumn{7}{|c|}{ Methods } \\
\hline & (1) & (2) & (3) & (4) & (5) & (6) & (7) \\
\hline Very low & \multirow{6}{*}{$\begin{array}{c}\text { Rosgen } \\
\text { (1996) }\end{array}$} & $>3.0$ & $<0.20$ & $<0.4$ & $<1.0$ & $<0.8$ & $<1.0$ \\
\hline Low & & $2.21-3.0$ & $0.20-0.40$ & $0.41-0.60$ & $1.0-1.5$ & $0.8-1.05$ & $1.0-1.2$ \\
\hline Moderate & & $2.01-2.2$ & $0.41-0.60$ & $0.61-0.80$ & $1.51-1.8$ & $1.06-1.14$ & $1.21-1.6$ \\
\hline High & & $1.81-2.0$ & $0.61-0.80$ & $0.81-1.0$ & $1.81-2.5$ & $1.15-1.19$ & $1.61-2.0$ \\
\hline Very high & & $1.5-1.8$ & $0.81-1.0$ & $1.01-1.2$ & $2.51-3.0$ & $1.20-1.60$ & $2.01-2.3$ \\
\hline Extreme & & $<1.5$ & $>1.0$ & $>1.2$ & $>3.0$ & $>1.6$ & $>2.3$ \\
\hline
\end{tabular}




\section{RESULTS AND DISCUSSION}

The relationship between the EB and BEHI on particular ES is depicted in Fig. 4. The results of the regression and correlation analysis showed a strong relationship existed $\left(\mathrm{R}^{2}=0.73\right)$. The strength of the relationship indicates that we were able to determine the most endangered sections, as the sections with the most severe bank erosion reached the highest BEHI value. Strong correlations between the BEHI and the EB were also reported by Rosgen $(1996,2001 b, 2008)$ in Colorado and Wyoming, Markowitz and Newton (2011) at the Birch Creek (New York state) or Dick et al. (2014) in Michigan.

On the other hand, there is also research available, where the relationship between the BEHI and the EB was weak or where there was no significant relationship whatsoever. These include studies by Coryat (2014), who found only a moderately strong relationship between the $\mathrm{EB}$ and the BEHI on the banks of the Stony Clove Creek $\left(\mathrm{R}^{2}=0.23\right)$, Macfall et al. (2014), who studied the Haw River in North Carolina or Saha and Mukhopadhyay (2014) on the Kunur River showed a weak relationship $\left(\mathrm{R}^{2}=0.14\right)$ between the EB and the BEHI.

Rosgen (1996) experienced discharges that were at most $60-70 \%$ of the bankfull stage. Researchers who experienced similar discharge stages, such as Markowitz and Newton (2011) or Dick et al. (2014), reported stronger relationships than authors who reported discharges greater than the bankfull stage. The authors who experienced greater than bankfull stage discharges include Coryat (2014), who reported high flood discharges that occurred during the hurricane Irene. He attributed the relatively weak relationship between the BEHI and the EB in his case to these extreme discharges. Macfall et al. (2014) too explain the weak relationship by the fact that the Haw River discharges frequently change from extremely low to extremely high. In our case, no extreme discharges occurred that would exceed the bankfull stage.

The relationship between the BEHI and the EB can be also affected by the precision with which the bank parameters are determined (e.g. the bank material, its stratification or the bank angles). In studies, where there was a weak relationship reported (Ghosh et al., 2016; Harmel et al., 1999; Kwan and Swanson, 2014), the authors used only visual assessments for bank parameters, whereas we used the sieve and densimetric tests to determine the bank material, and a laser clinometer to determine the bank angle. As Bigham et al. (2018) state, inaccurate determination of these parameters (especially study bank height, root depth, bank angle, and bank material) affects the estimation of the erodibility potential, thus affecting the relationship between the potential and the real erosion.

Of course, bank erosion depends on many other interconnected factors, be it climate, geology, vegetation, soil types and soil properties, human interaction with the channels, etc. (Sass, 2011). Besides the similar discharge stages and the fact that we measured the bank material and bank angles, the good fit of the BEHI and the EB could be caused by the relatively similar climatic conditions in our and Rosgen's research. Both Rosgen and we conducted the research in the humid continental climate zone. Geology of the studied areas was also similar - both our and Rosgen's study areas were located on sedimentary floors. Moreover, the studied streams had similar discharge behaviour throughout the year. Rosgen (1996) states that the discharges in the streams he observed culminate in spring and early summer due to snowmelt from the Rocky Mountains, with another culmination during summer due to extreme precipitation. We observed similar behaviour on the Tŕstie stream, which is located in the Biele Karpaty Mountains (a part of the Western Car-



Fig. 4. Relationship between the BEHI and the observed annual stream bank erosion (EB) $\left(\mathrm{m}^{3} \mathrm{~m}^{-1} \mathrm{yr}^{-1}\right)$.

pathians). These similarities contributed to the applicability of the BANCS model on the Tŕstie stream.

Conversely, there are environmental factors that could have prevented a better fit between the modelled and real bank erosion. Perhaps the most important is the fact, that Rosgen (1996) studied a large area with 49 streams, whereas we only applied his model to one low order stream with a small watershed. A larger area means a greater variability of vegetation, climate, and geology that translate to a more varied bank material composition, bank vegetation, channel characteristics, etc. The relationship between the BEHI and the EB could also be affected by the fact that Rosgen's study area experienced lower mean annual precipitation. The mean annual precipitation in Colorado is between 200 and $810 \mathrm{~mm}$ (Scott et al., 2003), whereas in the area where the Tŕstie watershed is located, Stankoviansky et al. (2012) report precipitation of 650 to $900 \mathrm{~mm}$. Furthermore, the Rocky Mountains are a larger mountain ridge, with higher peaks that contain vegetation and climate zones not found within the Biele Karpaty Mountains. Even so, these differences did not outweigh the similarities of our and Rosgen's study areas.

The relationship between the EB and the NBS index had similar properties (Fig. 5). A coefficient $\mathrm{R}^{2}=0.63$ showed there was a strong relationship between the EB and the NBS index. Harmel et al. (1999) studied the watershed of the Illinois River, and reached a substantially lower value of $\mathrm{R}^{2}=0.17$. They identified the cause of such weak correlation was the method they used to determine the NBS index, which was, according to the authors, relatively easy to carry out, but less precise. They advise to employ the method of velocity gradients.

We were able to create two erosion prediction curves (Fig. 6) - one for the L and M BEHI categories (Eq. 4), and one for the $\mathrm{H}, \mathrm{VH}$, and E BEHI categories (Eq. 5).

EB $\left(\mathrm{m}^{3} \mathrm{~m}^{-1} \mathrm{yr}^{-1}\right)=-0.036+0.0392 \mathrm{NBS}$

$\mathrm{EB}\left(\mathrm{m}^{3} \mathrm{~m}^{-1} \mathrm{yr}^{-1}\right)=-0.0194+0.0325 \mathrm{NBS}$

The constructed equations were used to estimate the erosion in particular ES, and the outcomes were subsequently compared to real EB (Table 6). The relationship between the predicted and real EB for L and M BEHI was moderately strong, with $\mathrm{R}^{2}=0.51$. The relationship between the predicted and real erosion for $\mathrm{H}, \mathrm{VH}$, and $\mathrm{E}$ BEHI was stronger, with $\mathrm{R}^{2}=0.66$. Many authors dealt with the problem of prediction curves. 


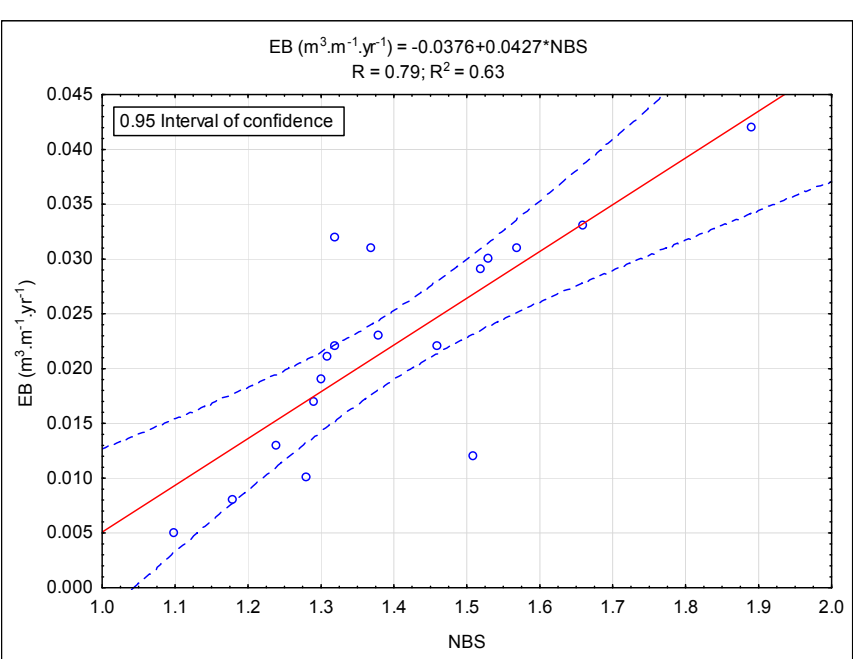

Fig. 5. Relationship between the NBS index and the observed annual streambank erosion.

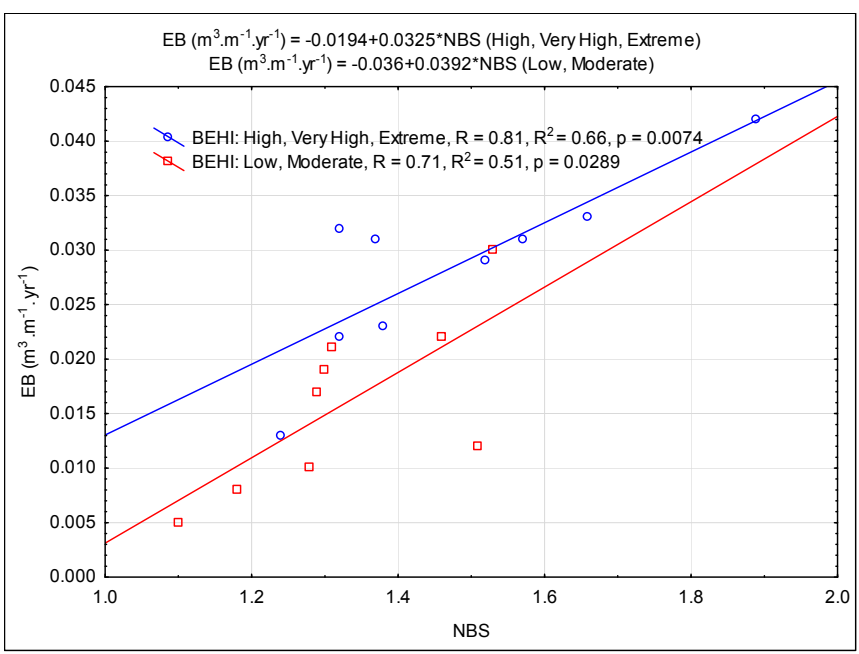

Fig. 6. Erosion prediction curves for Tŕstie creek.

Table 6. Comparison of real measured annual erosion rates (EB) $\left(\mathrm{m}^{3} \mathrm{~m}^{-1} \mathrm{yr}^{-1}\right)$ and predicted annual erosion (EBP) $\left(\mathrm{m}^{3} \mathrm{~m}^{-1} \mathrm{yr}^{-1}\right)$ by prediction curves.

\begin{tabular}{|l|c|c|c|}
\hline & $\begin{array}{c}\text { EB } \\
\left(\mathrm{m}^{3} \mathrm{~m}^{-1} \mathrm{yr}^{-1}\right)\end{array}$ & $\begin{array}{c}\text { EBP } \\
\left(\mathrm{m}^{3} \mathrm{~m}^{-1} \mathrm{yr}^{-1}\right)\end{array}$ & Difference \\
\hline ES1 & 0.013 & 0.021 & -0.008 \\
\hline ES2 & 0.042 & 0.042 & 0 \\
\hline ES3 & 0.032 & 0.024 & 0.008 \\
\hline ES4 & 0.03 & 0.024 & 0.006 \\
\hline ES5 & 0.023 & 0.015 & 0.008 \\
\hline ES6 & 0.031 & 0.025 & 0.006 \\
\hline ES7 & 0.033 & 0.035 & -0.002 \\
\hline ES8 & 0.029 & 0.030 & -0.001 \\
\hline ES9 & 0.031 & 0.032 & -0.001 \\
\hline ES10 & 0.022 & 0.024 & -0.002 \\
\hline ES11 & 0.012 & 0.023 & -0.011 \\
\hline ES12 & 0.017 & 0.015 & 0.002 \\
\hline ES13 & 0.021 & 0.015 & 0.006 \\
\hline ES14 & 0.01 & 0.014 & -0.004 \\
\hline ES15 & 0.023 & 0.025 & -0.002 \\
\hline ES16 & 0.005 & 0.007 & -0.002 \\
\hline ES17 & 0.008 & 0.010 & -0.002 \\
\hline ES18 & 0.022 & 0.021 & 0.001 \\
\hline
\end{tabular}

Coryat (2014) constructed the prediction curve on the Stony Clove Creek for an $\mathrm{H}$ and VH BEHI. He reported a weak relationship $\left(\mathrm{R}^{2}=0.35\right)$. Similarly, low determination was also reported by Harmel et al. (1999). For E BEHI, they reported $\mathrm{R}^{2}=0.15$, for $\mathrm{H}$ and $\mathrm{VH}$ BEHI categories, $\mathrm{R}^{2}$ was 0.09 , and for the M BEHI category, the $\mathrm{R}^{2}$ was 0.32 . They explain the weak relationships between the predicted erosion and the EB by the weak correlation of the NBS index with the EB.

Kwan and Swanson (2014) constructed the prediction curves for the Sequoia National Forest California catchment area based on data from multiple streams. They achieved better results, and some of their prediction curves can be used to predict EB in the catchment area. The coefficient of determination for the $\mathrm{E}$ BEHI category reached 0.76 , for the $\mathrm{H}$ and $\mathrm{VH}$ categories it reached 0.37 , for the $\mathrm{MBEHI}$ category is was 0.49 , and for the L category is was 0.70 . Sass (2011) reported that for the Black Vermillion watershed (north east Kansas), the coefficient of determination for the M BEHI category was 0.80 , and for the $\mathrm{H}$ and $\mathrm{VH}$ categories it was 0.42 . For the Piedmont region of North Carolina, the North Carolina State University constructed four prediction curves for the E BEHI category $\left(\mathrm{R}^{2}=0.91\right)$, the VH BEHI category $\left(\mathrm{R}^{2}=0.66\right)$, the H BEHI category $\left(\mathrm{R}^{2}=\right.$ 0.53 ), and for the M BEHI category, $\mathrm{R}^{2}$ was 0.92 (North Carolina State University (NCSU) Stream Restoration Program, 1989). Perhaps the most important study, in which the prediction curves were constructed, is from Rosgen (1996). It shows the prediction curves for the Colorado region. The author reports a strong relationship, with an $\mathrm{R}^{2}$ of 0.92 , and for the Yellowstone region, where he reported an $\mathrm{R}^{2}$ of 0.84 .

\section{CONCLUSION}

We found that the BANCS model is a viable tool for predicting bank erosion on the Tŕstie stream. The BEHI proved to be an adequate predictor of bank erosion in this stream. However, the NBS index showed a greater variability, which lead to weaker relationships between the predicted and real erosion. This could be due to the method we used to determine the NBS index, as other methods could provide more precise results. A more precise determination of the NBS index could enable even better fitting curves for predicting erosion. The constructed erosion prediction curves can be used for the studied stream in years when the discharge reaches bankfull stage flow at $Q_{50}$. The prediction curves are not suitable for use when the flow is higher than bankfull stage flow or extremely low, because they would significantly overestimate or underestimate erosion from the banks.

We used an erosion prediction method that was never before used in Central Europe. The model bases the predictions on relatively easy to measure parameters and can predict bank erosion relatively precisely. In our next research, we plan to integrate the monitoring of high flow in channel and precipitation in the watershed into the BANCS model, as the current model does not take these characteristics into account, despite the fact that the amount of water in the stream channel is the most important factor influencing bank erosion rate.

Acknowledgements. This article was financed by project APVV-15-0714: Mitigation of climate change risk by optimization of forest harvesting scheduling.

\section{REFERENCES}

Bandyopadhyay, S., Saha, S., Ghosh, K., De, S.K., 2013. Validation of BEHI model through field generated data for as- 
sessing bank erosion along the river Haora, West Tripura, India. Earth Sci. India, 6, 126-135.

Bigham, K.A., Moore, T.L., Vogel, J.R., Keane, T.D., 2018. Repeatability, Sensitivity, and Uncertainty Analyses of the BANCS Model Developed to Predict Annual Streambank Erosion Rates. JAWRA J. Am. Water Resour. Assoc., 1-17.

Bull, L.J., 1997. Magnitude and variation in the contribution of bank erosion to the suspended sediment load of the River Severn, UK. Earth Surface Processes and Landforms, 22, 12, 1109-1123.

Coryat, M., 2014. Analysis of the Bank assessment for non-point source consequences of sediment (BANCS) Approach for the prediction of streambank stability and erosion along Stony Clove Creek in the Catskills. Syracuse University, 78 p.

Dick, B.M., Hey, R., Peralta, P., Jewell, I., Simon, P., Peszlen, I., 2014. Estimating annual riverbank erosion rates - a dendrogeomorphic method. River Res. Appl., 30, 845-856.

Foucher, A., Salvador-Blanes, S., Vandromme, R., Cerdan, O., Desmet, M., 2017. Quantification of bank erosion in a drained agricultural lowland catchment. Hydrological Processes, 31, 6, 1424-1437.

Ghosh, K.G., Pal, S., Mukhopadhyay, S., 2016. Validation of bancs model for assessing stream bank erosion hazard potential (SBEHP) in Bakreshwar river of Rarh Region, Eastern India. Model. Earth Syst. Environ., 2, 1-15.

Harmel, R.D., Haan, C.T., Dutnell, R.C., 1999. Evaluation of Rosgen's streambank erosion potential assessment in Northeast Oklahoma. JAWRA J. Am. Water Resour. Assoc., 35, 113-121.

Jakubis, M., 2014. Predikcia erózie brehu vodného toku metódou BANCS (BEHI-NBS). In: Rožňovský, J., Litschmann, T., Středa, T., Středová, H. (Eds): Extrémy oběhu vody v krajině. Mikulov, Czech Republic, 2014, 12 p. ISBN 978-80-87577-30-1.

Jakubisová, M., 2014. Modelovanie brehov erózie metódou BSTEM $\mathrm{v}$ súvislosti $\mathrm{s}$ extrémnymi prietokmi. In: Rožňovský, J., Litschmann, T., Středa, T., Středová, H. (Eds): Extrémy oběhu vody v krajině. Mikulov, Czech Republic, 2014, 17 p. ISBN 978-80-87577-30-1.

Jennings, G.D., Harman, W.A., 2001. Measurement and stabilization of streambank erosion in North Carolina. In: Proc. Int. Symp. Soil Erosion Research for the 21st Century. ASAE, Honolulu, HI, pp. 537-540.

Kwan, H., Swanson, S., 2014. Prediction of annual streambank erosion for Sequoia National Forest, California. JAWRA J. Am. Water Resour. Assoc., 50, 1439-1447.

Laubel, A., Kronvang, B., Hald, A.B., Jensen, C., 2003. Hydromorphological and biological factors influencing sediment and phosphorus loss via bank erosion in small lowland rural streams in Denmark. Hydrological Processes, 17, 17, 3443-3463.

Lawler, D.M., Grove, J.R., Couperthwaite, J.S., Leeks, G.J.L., 1999. Downstream change in river bank erosion rates in the Swale-Ouse system, northern England. Hydrological Processes, 13, 7, 977-992.

Macfall, J., Robinette, P., Welch, D., 2014. Factors influencing bank geomorphology and erosion of the Haw River, a high order river in North Carolina, Since European Settlement. PLoS One, 9, 12 p.

Markowitz, G., Newton, S., 2011. Using Bank Assessment for Non-Point Source Consequences of Sediment (BANCS) Model to Prioritize Potential Stream Bank Erosion on Birch Creek, Shandaken, Ashokan Watershed Stream Management Program (AWSMP). New York, 57 p.
North Carolina State University (NCSU) Stream Restoration Program, 1989. North Carolina Piedmont Region Bank Erosion Prediction Curve. Available at: http://www.bae.ncsu.edu/ programs/ extension/wqg/srp/. Accessed 2 January 2014.

Rosgen, D.L., 1996. Applied River Morphology. Wildland Hydrology, Pagosa Springs, CO, 380 p.

Rosgen, D.L., 1998. Field Guide for Stream Classification. Wildland Hydrology, Pagosa Springs, CO, 193 p.

Rosgen, D.L., 2001a. A hierarchical river stability/Watershedbased sediment assessment methodology. In: Proc. 7th Federal Interagency Sedimentation Conference. Reno, NV, p. 13.

Rosgen, D.L., 2001b. A practical method of computing streambank erosion rate. In: Proc. 7th Federal Interagency Sedimentation Conference. Reno, NV, pp. 9-15.

Rosgen, D.L., 2006. Watershed assessment of river stability and sediment supply (WARSSS). Wildland Hydrology, Fort Collins, CO, 648 p.

Rosgen, D.L., 2008. River Stability: Field Guide. Wildland Hydrology, Fort Collins, CO, 214 p.

Rusnák, M., Lehotský, M., 2014. Povodne, brehová erózia a laterálne presúvanie koryta štrkonosných kl’ukatiacich vodných tokov (prípadová štúdia tokov Topl'a a Ondava). Acta Hydrologica Slovaca, 15, 424-433.

Saha, S., Mukhopadhyay, S., 2014. A study on Kunur River, Eastern India. Int. J. Geol. Earth Environ. Sci., 4, 216-223.

Sass, C.K., 2011. Evaluation and development of predictive streambank erosion curves for Northeast Kansas using Rosgen's "BANCS" Methodology. Kansas State University, $141 \mathrm{p}$.

Sass, C.K., Keane, T.D., 2012. Application of Rosgen's BANCS model for NE Kansas and the development of predictive streambank erosion curves. J. Am. Water Resour. Assoc., 48, 774-787.

Scott, L.S., Collins, O.C., Diggs, M.D., 2003. Atlas of Colorado. A Teaching Resource. Downloaded 26. 02. 2018. Avaliable on http://www.unco.edu/hss/geographygis/pdf/atlas/atlas-full-reduced.pdf, $194 \mathrm{p}$.

Stankoviansky, M., Frandofer, M., 2012. Reliéf katastrálneho územia Starej Turej a jeho recentný vývoj. Geogr. Cassoviensis, 6, 59-73.

Stankoviansky, M., Barka, I., Bella, P., Boltižiar, M., Grešková, A., Hók, J., Ištok, P., Lehotský, M., Michalková, M., Minár, J., Ondrášik, M., Ondrášik, R., Pecho, J., Pišút, P., Trizna, M., Urbánek, J., 2012. Recent landform evolution in Slovakia. In: Recent Landform Evolution: The CarpathoBalkan-Dinaric Region. Springer, Dordrecht, Heidelberg, London, New York, pp. 141-175.

Szolgay, J., Hlavčová, K., Parajka, J., Čunderlík, J., 1997. Vplyv klimatickej zmeny na odtokový režim na Slovensku [The effect of climate change on the run-off regime in Slovakia]. Zborník NKP SR 6, 110 p.

Van Eps, M.A., Formica, S.J., Morris, T.L., Beck, J.M., Cotter, A.S., 2004. Using a Bank erosion hazard index (BEHI) to estimate annual sediment loads from streambank erosion in the West Fork White River watershed. In: Arkansas watershed advisory group conference proceedings: Self-sustaining solutions for streams, wetlands, and watersheds. pp. 125-132.

Veihe, A., Jensen, N.H., Schiøtz, I.G., Nielsen, S.L., 2011. Magnitude and processes of bank erosion at a small stream in Denmark. Hydrological Processes, 25, 10, 1597-1613.

Received 29 May 2017 Accepted 28 February 2018 